\title{
Nematicidal Effect of Some Botanical Powders and Poultry Manure Against the Root-Knot Nematode Meloidogyne incognita (Kofoid and White) Chitwood infecting Tomato Plants
}

\author{
M. R. M. Saeed and J. N. Shawkat \\ Department of Plant Protection, Faculty of Agriculture, Sana'a University, Yemen. \\ E-mail: raweh2001@yahoo.com
}

\begin{abstract}
A greenhouse experiment was conducted to evaluate the efficacy of soil amendment with six botanical leaves powders and poultry manure in controlling Meloidogyne incognita infecting tomato and their potency in growth improvement. The result of the study showed that all the treatments significantly $(p \leq 0.05)$ reduced root galling, second-stage juveniles in soil, developmental stages and egg masses and reductions differed according to the amended materials. Although all treatments were effective in reducing root galls and nematode population, soil treated with leaves powder of Peganum harmala gave the highest reduction in nematode criteria followed by Datura stramonium and Nicotiana glauca, However, Azadirachta indica had the least reduction compared to the untreated check. The efficacy increased with the increase in dosage rates except with poultry manure at the highest dosage. Most soil amendments at different dosage rates significantly improved the shoot and root weights. Peganum harmala achieved the highest increase, while Azadirachta indica gave the lowest one.
\end{abstract}

Keywords: Meloidogyne incognita, botanical amendments, tomato, poultry manure.

\section{Introduction}

Tomato (Lycopersicon esculentum Mill.) is the second important vegetable crop in Yemen and is cultivated in over 18274 hectares with a production of about 258654 meter tons in 2012 (Anonymous, 2013). Root knot nematodes (Meloidogyne spp.) are one of the major pests of tomato worldwide and limit its production (Sikora and Fernandez, 2005). Tomato infected by nematodes record yield losses up to $80 \%$ in heavily infested soils (Kaskavalci, 2007). In Yemen, $M$. incognita (Kofoid \& White, 1919) Chitwood, 1949 has been regarded as a serious pest of tomato causing severe losses in tomato yield especially in plastic houses and tunnels. Because of the extensive use of chemical nematicides such as methyl bromide in Yemen, especially in greenhouses, they create hazardous problems to human, animals and environment; and are relatively unaffordable to the average small scale farmer (Tsay et al., 2004 and Washira et al., 2009). Therefore, soil amendment with dry ground leaves of plant products and poultry manures have been successfully used for the control of plant-parasitic nematodes and improve plant growth when added to soil (Muller and Gooch, 1982; Alam, 1990; Akhtar 
and Mahmood, 1996; Akhtar and Malik, 2000; Kheir, et al., 2000; Wani, 2006; Ahmad, et al., 2007; Ibrahim, et al., 2007; Radwan, et al., 2007; Wiratno et al., 2009; Moosavi, 2012; Ishaku and Ahaji, 2013; Ojo and Umar, 2013 and Youssef and Lashein, 2013).

Soil amendments of either plant or animal origin and poultry manure have beneficial advantageous effects on soil physical condition, nutrients, fertility and biological activities (Hungalle et al., 1986; Akhtar and Malik, 2000). Moreover, they release chemical compounds during their decomposition in soil those act as nematicides (Mian and Rodriguez-Kabana 1982; Sukul, 1992; Akhtar and Alam, 1993; Miano, 1999 and Chitwood, 2002).

The objective of this study was to:

1. Evaluate the nematicidal activity of dried-ground leaves of six plant species (Argemone mexicanai, Azadirachta indica, Datura innoxia, Datura stramonium, Nicotiana glauca and Peganum harmala);

2. Poultry manure when used as soil amendments against the root-knot nematode, M. incognita infecting tomato under glasshouse conditions.

\section{Materials and Methods}

\section{Collection and Preparation of plant Leaves and poultry manure:}

Leaves of Argemone mexicanai, Azadirachta indica, Datura innoxia, Datura stramonium, Nicotiana glauca and Peganum harmala were separately collected during the summer season of 2013 from different plants at different locations of Sana, a University, Yemen. The leaves were air-dried on laboratory benches for two weeks at $20-30^{\circ} \mathrm{C}$. Then, they were ground separately into fine powders with Thomas Wiley laboratory mill and electric Waring blinder and stored in sealed containers until using. Dried chicken manure was obtained from a poultry farm ground and sieved over a $0.5-\mathrm{cm}$ sieve.

\section{Preparation of Inocula:}

The root-knot nematode, $M$. incognita culture was initiated from single egg masses of previously identified females (Taylor et al., 1955) and isolated from galled roots of highly infected tomatoes collected from Sahar, Sadah governorate and propagated on eggplant cv. Long purple in a glasshouse at Sana'a University. Adequate second stage juveniles (J2) were obtained from the infected host plant to prepare the needed nematode inocula.

\section{Greenhouse Experiment:}

Rio Grande tomato seeds were germinated in foam boxes filled with sterilized sand and peatmoss (1:2, w:w). Six weeks-old seedlings were singly transplanted in 15-cm. diameter plastic pots filled with steam sterilized loamy sand soil (1:2, w:w). Ten days after transplanting 5, 10 and $15 \mathrm{~g}$ (equilvalent to 5.7,11.4 and 17.1 t/ha, 
respectively) of leaves powders were incorporated on top of soil around the base of each plant except those of the check. Poultry manure was applied at the rate of 2, 4 and $6 \mathrm{~g} /$ pot. Each treatment including the check was replicated 5 times.

Ten days later each plant was inoculated with 800 freshly hatched juveniles of $M$. incognita by pipetting the juveniles suspension in 5 holes around the root system. Five plants were kept without inoculation to serve as a check treatment. All pots were arranged in a randomized block design on a greenhouse bench at temperature degrees of $25 \mathrm{C}^{\circ} \pm 5$. All plants received similar treatments of fertilizing and irrigation. Sixty days after inoculation, the experiment was ended and all plants were rooted-off and nematode counts in both soil and roots were estimated. Plant growth criteria on the basis of shoot and root length and fresh weight were measured. Data were subjected to analysis of variance and means were compared at $P=0.05$ using SPSS software version 19 .

\section{Results}

\section{Antagonistic effect of the tested materials on the nematode development and reproduction:}

As shown in Table (1) all applied treatments caused significant reduction in numbers of root galls, nematode population in soil, development of stages and egg masses in all treatments in comparison to that of the check. Efficacy of the materials differed according to the plant species and dosage rate. Generally, by increasing the amendment dosage rate, the efficacy was also increased (except in treatment of poultry manure). Leaves powder of Peganum harmala was the most effective in reducing gall formation, counts in soil, developmental stages, egg masses and final population at the different rates, followed by Datura stramonium and Nicotiana glauca; while the lowest \% reduction in such nematode parameters was recorded in case of the soil amended with Azadirachta indica followed by Argemone mexicanai. Insignificant differences were observed between treatments of leaves powder of Peganum harmala and Datura stramonium at all dosage rates in values of numbers of galls, counts in soil, and developmental stages. The modest dosage rate $(4 \mathrm{gm})$ of poultry manure had considerable more effect on number of galls and nematode criteria with 2.9 build up than other dosage rates. There were no significant differences in number of eggs per egg mass between the check and those treated with Argemone mexicanai, Azadirachta indica and poultry manure at different rates; and with Datura innoxia and Datura stramonium at rate $5 \mathrm{gm}$. Accordingly, the nematode final population and its rate of build-up were also affected. Treatments of all soil amendments at different dosage rates had lower rates of build-up $(0.4-15.5)$ than that of the check (39.3). Peganum harmala at all dosage rates achieved the lowest rate of build-up $(0.4,0.6$ and 1.7$)$, followed by Datura stramonium (0.5, 2.2 and 1.8). The highest rates of build up. (15, 14 and 12) were obtained by Azadirachta indica at lowest and modest dosage rate and Nicotiana glauca at lowest dosage rate, respectively. 


\section{Effect of the tested materials on growth of tomato plants:}

With regard to the effects of botanical and poultry soil amendments on tomato growth, data in table (2) reveal that most soil amendment, at different dosage rates, significantly improved growth parameters of shoot and root fresh weights except for Datura stramonium and poultry manure at lowest dosage rates in case of shoot weight and for Azadirachta indica at different dosage rates and Argemone mexicanai at the lowest and modest dosage rates and lowest dosage rate for Peganum harmala in case of root weight. On the other hand, most tested soil amendments at different dosage rates caused insignificant\% increase in shoot and root lengths except for Argemone mexicanai and poultry manure at modest dosage rates and Azadirachta indica at different dosage rates in case shoot length and for Azadirachta indica and Datura stramonium at highest dosage rate in case of root length. Generally, shoot fresh weight increased with increasing in the dosage rates of all leaves powders and poultry manure The highest shoot fresh weight was recorded in plants amended with leaves powder of Peganum harmala and Nicotiana glauca at highest and modest dosage rates where they caused 192, 187, 154 and $139 \%$ increase, respectively. Contrary, the lowest percentages of increase were obtained by lowest dosage rate of poultry manure, Datura stramonium and Azadirachta indica with 26, 39 and $54 \%$ increase, respectively. On the other hand, the highest root fresh weight was recorded in the plants treated with the leaves powder of Peganum harmala at highest dosage rate with $213 \%$ increase followed by the lowest dosage rate of poultry manure and the highest dosage rate of Datura stramonium with $191 \%$ and $184 \%$ increase, respectively.

\section{Discussion}

Amending soil with leaves powder of the tested plants and poultry manure suppressed gall formation and population of $M$. incognita both in soil and roots of tomato plants with a concomitant increase in plant growth compared to the untreated check.

When the dosage rate of leave powder was increased, nematode infection and reproduction rate decreased. These results are parallel with those obtained by Kheir et al., 2000; Hosseininejad, 2004; Radwan, et al., 2007; Ntalli et al., 2010b; Onyeke and Akueshi, 2012 and Cavoski et al., 2012. Peganum harmala performed the best effect in reducing numbers of root galls, juveniles in soil, developmental stages and egg masses of $M$. incognita followed by Datura stramonium at the different dosage rates in comparison to those of the check. This could be attributed to production of strong nematicidal substances like harmal's alkaloids including $\beta$-carboline as harmine, harmaline, harmalol, harmol and harman and quinazolines as vaccine and vasicinone (El-Hassan et al., 2013). Active ingredients of $D$. stramonium are atropine, hyoscyamine and scopolamine which 
Table (1): Effect of some botanical powders and Poulty menure on development and reproduction of Meloidogyne incognita infecting tomato.

\begin{tabular}{|c|c|c|c|c|c|c|c|c|c|c|c|c|c|}
\hline \multirow{3}{*}{ Trea tments } & \multirow{3}{*}{$\begin{array}{l}\text { Dose } \\
\text { gm. }\end{array}$} & \multicolumn{2}{|c|}{ Galls } & \multicolumn{10}{|c|}{ Nematode counts } \\
\hline & & \multirow[b]{2}{*}{ No. } & \multirow[b]{2}{*}{ \%ped. } & \multicolumn{2}{|c|}{ In 60ll } & \multicolumn{6}{|c|}{ In root } & \multirow{2}{*}{$\begin{array}{c}\text { Final } \\
\text { populat on }\end{array}$} & \multirow{2}{*}{$\begin{array}{l}\text { Bulld up } \\
\text { (PIIPI) }\end{array}$} \\
\hline & & & & No. & \%Rिd & \multicolumn{2}{|c|}{ D. 6 t g95 } & \multicolumn{2}{|c|}{ Eggmasses } & \multicolumn{2}{|c|}{ Egg5/EM. } & & \\
\hline & 5 & $556 \mathrm{efon}^{\prime \prime c h}$ & 59 & $6913 \mathrm{~g}$ & 76 & 574 efogn & 61 & 359 II & 43 & $995 \mathrm{nl}$ & $\frac{10 \text { hese. }}{0}$ & 7845 & 9.81 \\
\hline \multirow[t]{3}{*}{ Argemone mexic anal } & 10 & 542 etgh & 60 & $6673 \mathrm{fg}$ & 77 & 561 efgh & 62 & $305 \mathrm{nl}$ & 52 & $982 \mathrm{ghl}$ & 2 & 7539 & $9.4 \%$ \\
\hline & 15 & 481 det & 64 & $5015 \mathrm{ef}$ & 83 & 499 det & 66 & $273 \mathrm{gh}$ & 57 & 399 efgh| & 10 & 5787 & $72 \mathrm{et}$ \\
\hline & 5 & $756 \mathrm{~h}$ & 44 & 11137 I & 62 & 7721 & 48 & 4881 & 23 & 11021 & -10 & 12397 & $15.5 \mathrm{~h}$ \\
\hline \multirow[t]{3}{*}{ Azadracha indica } & 10 & $739 \mathrm{nl}$ & 45 & $10611.2 \mathrm{ml}$ & 64 & $758 \mathrm{nl}$ & 49 & 489.81 & 22 & 938 fghl & 6 & 11859 & $14.8 \mathrm{n}$ \\
\hline & 15 & $729 \mathrm{ghl}$ & 46 & 4323 de & 85 & $747 \mathrm{ghl}$ & 50 & $424 \mathrm{k}$ & 33 & $1031 \mathrm{hl}$ & -3 & 5494 & $69 \mathrm{e}$ \\
\hline & 5 & 625 fghl & 54 & 3981 de & 86 & $652 \mathrm{fghl}$ & 56 & $376 \mathrm{~K}$ & 40 & 837 defgh & 16 & 5009 & $6.3 \mathrm{de}$ \\
\hline \multirow[t]{3}{*}{ Dawra Innoxia } & 10 & 428 ode & 68 & 3671 ode & 87 & 449 odef & 70 & $258 \mathrm{gh}$ & 59 & 765 coet & 23 & 4378 & $5.5 \mathrm{de}$ \\
\hline & 15 & 360 ode & 73 & $1045 a b$ & 96 & 376 ode & 75 & $173 \mathrm{ef}$ & 72 & 643 bod & 35 & 159 & $2 a b c$ \\
\hline & 5 & $252 a b c$ & 81 & $1050 a b$ & 96 & $267 a b c$ & 82 & 151 de & 76 & 295 efghl & 10 & 1478 & $1.8 \mathrm{abc}$ \\
\hline \multirow[t]{3}{*}{ Davra suamonium } & 10 & $235 a b c$ & 83 & $1315 a b$ & 96 & $249 \mathrm{abc}$ & 83 & $175 \mathrm{ef}$ & 72 & 767 coet & 23 & 1739 & $2.2 a b c$ \\
\hline & 15 & $130 \mathrm{ab}$ & 90 & $152 \mathrm{a}$ & 99 & $146 \mathrm{ab}$ & 90 & $82 a b c$ & 87 & 640000 & 36 & 380 & $0.5 \mathrm{a}$ \\
\hline & 5 & $493 \mathrm{det}$ & 63 & $9282 \mathrm{~h}$ & 68 & 492 def & 67 & $308 \mathrm{ml}$ & 51 & 783 odefg & 22 & 10083 & $12.6 \mathrm{~g}$ \\
\hline \multirow[t]{3}{*}{ Nicodara glauca } & 10 & 320 000 & 76 & $2053 a b c$ & 93 & $286 a b c$ & 81 & 126 ode & 80 & 713 ode & 29 & 2466 & $3.1 \mathrm{bc}$ \\
\hline & 15 & $222 a b c$ & 83 & 855 ab & 97 & $260 a b c$ & 82 & 126 ode & 80 & $597 \mathrm{abc}$ & 40 & 1241 & $1.6 \mathrm{ab}$ \\
\hline & 5 & $274 a b c$ & 80 & 989 ab & 97 & $291 \mathrm{abc}$ & 80 & 97 abod & 85 & $508 \mathrm{ab}$ & 49 & 1377 & $1.7 \mathrm{ab}$ \\
\hline \multirow[t]{3}{*}{ Peganum harmala } & 10 & $123 \mathrm{ab}$ & 91 & $313 \mathrm{a}$ & 99 & $134 a b$ & 91 & $44 a b$ & 93 & $485 \mathrm{ab}$ & 52 & 491 & $0.6 \mathrm{a}$ \\
\hline & 15 & $80 \mathrm{a}$ & 94 & $200 \mathrm{a}$ & 99 & $91 \mathrm{a}$ & 94 & $39 \mathrm{a}$ & 94 & $435 \mathrm{a}$ & 57 & 330 & $0.4 \mathrm{a}$ \\
\hline & 2 & $1062 \mathrm{~J}$ & 21 & $4636 \mathrm{e}$ & 84 & $1090 \mathrm{~J}$ & 26 & 257 gh & 59 & $1045 \mathrm{hl}$ & 6 & 5983 & $7.5 \mathrm{et}$ \\
\hline \multirow[t]{2}{*}{ Poulty manure } & 4 & 309 bod & 77 & $1901 \mathrm{abc}$ & 94 & 334 bod & 77 & 105 bod & 83 & $1021 \mathrm{hl}$ & -2 & 2340 & $29 \mathrm{abc}$ \\
\hline & 6 & 533 efg & 60 & 2590 bod & 91 & 554 efg & 63 & $233 \mathrm{fg}$ & 63 & 843 defgh & 16 & 3376 & 42 ot \\
\hline Check & & $1345 \mathrm{k}$ & 0 & $29336 \mathrm{k}$ & 0 & $1482 \mathrm{k}$ & 0 & $630 \mathrm{~m}$ & 0 & $999 \mathrm{hl}$ & 0 & 31448 & 39.31 \\
\hline
\end{tabular}

Means followed by the same leter(s) w Whin a column a not $s$ gnificantly ditferent $(p-0.05)$ according to Duncan's murtiple range test. 


\begin{tabular}{|c|c|c|c|c|c|c|c|c|c|}
\hline \multirow{2}{*}{ Treatments } & \multirow{2}{*}{$\begin{array}{l}\text { Dose } \\
\text { gm. }\end{array}$} & \multicolumn{4}{|c|}{ shoot } & \multicolumn{4}{|c|}{ Root } \\
\hline & & Velghtigm) & $\%$ Increase & Length(cm) & $\%$ Increase & Vkilght(gm) & $\%$ increase & Length $(\mathrm{cm})$ & $\%$ increase \\
\hline \multirow{4}{*}{ Argemone max Icanal } & 5 & 82.2 bodet & 72 & $56.4 \mathrm{abc}$ & 13 & $26.5 \mathrm{abc}$ & 48 & $27.3 \mathrm{ab}$ & 6 \\
\hline & 10 & 99.8 detgh & 109 & $67.4 \mathrm{c}$ & 35 & $25.1 \mathrm{ab}$ & 40 & $252 a$ & -2 \\
\hline & 15 & $107.8 \mathrm{fgh}$ & 126 & $62 \mathrm{abc}$ & 24 & 37.4 det & 109 & $27.7 \mathrm{abc}$ & 7 \\
\hline & 5 & 73.7000 & 54 & $67.7 \mathrm{c}$ & 35 & $19.6 \mathrm{a}$ & 9 & $26.8 \mathrm{a}$ & 4 \\
\hline \multirow[t]{3}{*}{ Azadiracha Indica } & 10 & 79 bose & 65 & $66.8 \mathrm{c}$ & 34 & 25.9 abc & 45 & $27.6 \mathrm{abc}$ & 7 \\
\hline & 15 & 86.9 odet & 82 & $67.7 \mathrm{C}$ & 35 & $259 a b c$ & 45 & $31.7 \mathrm{bc}$ & 23 \\
\hline & 5 & 81.3 bodef & 70 & $57.3 \mathrm{abc}$ & 15 & 35 bose & 96 & $29.1 \mathrm{abc}$ & 13 \\
\hline \multirow[t]{3}{*}{ Dawura innoxia } & 10 & 85.2 boset & 78 & $60.6 \mathrm{abc}$ & 21 & $37.3 \mathrm{det}$ & 108 & $26.6 \mathrm{a}$ & 3 \\
\hline & 15 & 96.2 defgh & 101 & $62.7 \mathrm{abc}$ & 25 & 33.7 bod & 88 & $246 \mathrm{a}$ & 6 \\
\hline & 5 & $66.4 \mathrm{abc}$ & 39 & $57.4 \mathrm{abc}$ & 15 & 44. 1 efg & 146 & $27.3 \mathrm{ab}$ & 6 \\
\hline \multirow[t]{3}{*}{ Davra suamonium } & 10 & 95.7 defgh & 100 & $54.8 \mathrm{abc}$ & 10 & $45.2 \mathrm{efg}$ & 153 & $28.8 \mathrm{abc}$ & 12 \\
\hline & 15 & $105.6 \mathrm{efgh}$ & 121 & $60.5 \mathrm{abc}$ & 21 & $50.8 \mathrm{gh}$ & 184 & 3220 & 25 \\
\hline & 5 & $1082 \operatorname{tgn}$ & 126 & $59.8 \mathrm{abc}$ & 20 & 30.6000 & 71 & $259 \mathrm{a}$ & 0 \\
\hline \multirow[t]{3}{*}{ Nic ot ana glauca } & 10 & $114.4 \mathrm{gnn}$ & 139 & $57.7 \mathrm{abc}$ & 15 & $38.5 \mathrm{def}$ & 115 & $28.3 \mathrm{abc}$ & 10 \\
\hline & 15 & 1372 IJ & 187 & $57.8 \mathrm{abc}$ & 16 & $44.2 \mathrm{efg}$ & 147 & 259 a & 0 \\
\hline & 5 & 91.3 odefg & 91 & $51.5 \mathrm{ab}$ & 3 & $27.1 \mathrm{abc}$ & 51 & $26.4 \mathrm{a}$ & 2 \\
\hline \multirow[t]{3}{*}{ Peganum harmala } & 10 & $121.3 \mathrm{nll}$ & 154 & $57.3 \mathrm{abc}$ & 15 & 36.2 odef & 102 & $28.4 \mathrm{abc}$ & 10 \\
\hline & 15 & 139.61 & 192 & $51.3 \mathrm{a}$ & 3 & $56 \mathrm{~h}$ & 213 & $28 a b c$ & 9 \\
\hline & 2 & $60.1 \mathrm{ab}$ & 26 & $52.6 \mathrm{ab}$ & 5 & $52 \mathrm{gh}$ & 191 & $29.3 \mathrm{abc}$ & 14 \\
\hline \multirow[t]{2}{*}{ Poultry manure } & 4 & 94.6 defgh & 98 & $64.6 \mathrm{dc}$ & 29 & $49 \mathrm{gh}$ & 174 & $27.2 \mathrm{ab}$ & 5 \\
\hline & 6 & 94.4 defgh & 97 & $50.6 \mathrm{a}$ & 1 & $46.1 \mathrm{fgh}$ & 158 & $27 \mathrm{ab}$ & 5 \\
\hline Check & & $47.8 \mathrm{a}$ & 0 & $50 \mathrm{a}$ & 0 & $18 \mathrm{a}$ & 0 & $25.8 \mathrm{a}$ & 0 \\
\hline
\end{tabular}


are classified as deliriants, or anticholinergics (Oduor-Owino, 1993) ;and amending soil with leaves were effective against the root-knot nematodes $M$. incognita on tomato (Chattopadhyay, 1991 and Radwan, et al., 2007). The N. glauca activity might be due to the presence of nicotine, the piperidine alkaloid from tobacco plant which can be toxic in high doses to both animals and human. Its high solubility in water could explain the high effect of its water extracts (Webb and Dalzell, 1997), Also, anabasine could be regarded as a highly toxic piperidine like alkaloid constituting about $70 \%$ of the plant as a whole (Mizrachi et al., 2000 and Mhinana et al., 2010). The nematicidal activity of $A$. indica can be attributed to its contents of tannins, azadirachtine, alkaloids and lipids associates such as nimbidol, nimbine, nimbidine, nimbinin, kemferol, pyronimbin, salannin, thionemone, etc., which possess nematicidal properties (Rossner and Zebitz, 1987; Akhtar, 2000; Fatoki, 2001 and Abbasi et al., 2004). Triglyceride was reported as a nematicidal compound in seeds of Argemone mexicana. Sanguinarine is a quaternary benzophenanthridine alkaloid with a strong bactericidal effect on Gram-positive bacteria (Rao and Dave, 2001) which may confer protection against diverse pathogens (Facchini, 2001). Sanguinarine and other identified alkaloids in Argemone include berberine, protopine and coptisine may cause nematicidal effects (Facchini, 2001).

Amending the soil with poultry manure significantly reduced counts of root galls, juveniles in soil, developmental stages, egg masses in root and final population of $M$. incognita, in addition, the usage of such materials did improve the plant growth. These result are in agreement with the findings of Kablan and Noe (1993), El-Zawahry, (2000), Ibrahim and Ibrahim, (2000) Maareg et al., (2000), Devi and Hassan (2002), Farahat et al., 2008 (Karmani et al.,( 2011) and Farahat et al.( 2012). The nematicidal activity of poultry manure is mainly attributed to its contents of volatile fatty acids, phenols, amino acids, ammonia, nitrites and gasses which released during the decomposition of the manure; and to enhance soil populations of micro-organisms antagonistic to nematodes (Badra, et al., 1979; Mian, Rodrequez-Kabana, 1982; Lazarovits et al., 2001; Oka and Pivonia, 2002; and Farahat et al., 2008). The observed increase in growth in tomato plants grown in treated soils compared to those in the untreated soils may be attributed to the effective nematode control and to imptovement in soil nutrients, soil physical conditions and soil biological activity (Akhtar and Malik, 2000; Ramesh et al., 2009; Oka, 2010 and Moosavi, 2012). Therefore, the using of dried leaves of the tested plants and poultry manure could offer a promising tool for nematode management for away from the traditional nematicides -Moreover, such materials are available, cheap, and safe environmentally. 


\section{References}

Abbasi, P.A.; Riga, E.; Conn, K.L. and Lazarovits, G. (2004).Effect of neem cake soil amendment on reduction of damping-off severity and population densities of plant-parasitic nematodes and soilborne plant pathogens. Canadian J. of Plant Pathol., 27: 38-45.

Ahmad, F.; Rather, M. A. and Siddiqui, M. A. (2007). Impact of organic soil amendments and nematicides on Meloidogyne javanica infecting tomato. Indian J. Nematol., 37: 55-57.

Akhtar, M. (2000)..Nematicidal potential of the neem tree (Azadirachta indica A.Juss.). Intrgd. Pest Mngmt. Rev., 5:57-66.

Akhtar, M. and Alam M. M. (1993). Utilization of waste materials in nematodes control: a review. Bioresour. Technol., 45:1-7.

Akhtar, M. and Mahmood, I. (1996).Organic amendments in relation to nematode management with particular reference to India. Intrgd. Pest Mngmt., 1 (4): 201-215.

Akhtar, M. and Malik A. (2000). Roles of organic soil amendments and soil organisms in the biological control of plant-parasitic nematodes: a review. Bioresour. Technol., 74:35-47.

Alam, M. M. (1990). Neem in biocontrol. In: Nematode Biocontrol (Aspects and Prospects) (Jairajpuri, M. S., Alam, M. M. and Ahmad, I. eds.). CBS Publishers and Distributers, Delhi, India, 17-40 pp.

Anonymous, (2013). Year Book,2012, Ministry of Agric. and Irrigation, Republic of Yemen.

Badra, T.; Saleh, M. A.; Oteifa, B. A. (1979).Nematicidal activity and decomposition of some organic fertilizers and amendments. Rev. Nematol., 4:311-317.

Cavoski, I.; Chami, Z. A. ; Bouzebboudja, F.; Sasanelli, N.; Simeone, V.; Mondelli, D.; Miano, T.; Sarais G.; Ntalli, N. G. and Caboni, P. (2012). Melia Azederach controls Meloidogyne incognita and triggers plant defence mechanisms on cucumber. Crop Protect., 35: 85-90.

Chattopadhyay, P. R. (1991).Nematicidal properties of some plant materials on tomato (Lycopersicon esculentum cultivar local) infested with Meloidogyne incognita. Geobios (Jodhpur), 18(5/6): 232-236.

Chitwood, D. J. (2002). Phytochemical based strategies for nematode control. Ann. Rev. Phytopathol., 40, 221-249.

Devi, L. S. and Hassan M. G. (2102). Effect of organic manures singly and in combination with Trichoderma viride against root knot nematode, Meloidogyne incognita of soybean (Glycine max L. Mrill). Indian J. Nematol., 32 (2): 190-192.

El-Hassan, M.; Ferji, Z. and Idrissi, H. L. (2013). Anti-nematode effect assessment of Peganum harmala based products against Meloidogyne javanica on melon. J. Biolo, Agric. and Healthcare, 3 (5):2224-3208. 
El-Zawahry, A. M. (2000). Effect of organic manure on infection of faba bean by root knot nematode. Assiut J. Agri. Sci., 31 (4): 79-88.

Facchini, P. J. (2001).Alkaloid biosynthesis in plants: biochemistry, cell biology, molecular regulation, and metabolic engineering applications. Ann. Rev. of Plant Physiol. and Plant Molec.r Biol., 52, p. 29-66.

Farahat, A. A.; Al-Sayed, A. A.; EL-Beltagi, H. S. and Nomair, M. M. (2012).Impact of organic and inorganic fertilizers on nematode reproduction and biochemical alterations on tomato. Not. Sci. Biol., 4(1):48-55.

Farahat, A. A.; El-Naggar, H. I.; Hendy, H. H. and El-Ghonaimy, A. M. (2008).Management of the root-knot nematode Meloidogyne incognita infecting peach, Prunus persica under greenhouse conditions. Egypt. J. Agronematol., 6(2): 127-146.

Fatoki, O. K. (2001). Comparative effects of carbofuran and some selected plant extracts on the biology and pathogenicityof Meloidogyne incognita on cowpea and tomato. Ph.D Thesis, Univ. of Ibadan, Nigeria, pp: 135.

Hosseininejad, S. A. (2004). Effect of neem, Azadirachta indica, on root-knot nematode, Meloidogyne javanica, infesting tomato. App. Entomol. and Phytopathol., 71: 69-89.

Hungalle, N.; Lal, R. and Terkuile, C. H. H. (1986).Amelioration of physical properties by Mucuna after mechanized land clearing of a tropical rainforest. Soil Sci., 141:219-224.

Ibrahim, A. A. M. and Ibrahim, I. K. A. (2000). Evaluation of non-chemical treatments in the control of Meloidogyne incognita on common bean. Pak. J. Nematol., 18 (1-2): 51-57.

Ibrahim, I.K.A.; EL-Saedy, M.A.M. and Asmaa, A. M. (2007). Control of the rootAnot nematode Meloidogyne incognita on sunflower plants with certain organic plant materials and biocontrol agents. Egypt. J. Phytopathol.,vol. 35, No. 1: pp. 13-24.

Ishaku, B. C. and Ahaji, M. B. (2013). Evaluation of organic soil amendments on the growth and yield of Meloidogyne incognita on cowpea. Plants J. Biol. Agric. and Healthcare ISSN 2224-3208 (Paper) ISSN 2225-093X (Online) vol.3, no.3, 2013

Kaplan, M.; Noe, J.P. (1993). Effects of chicken excrement amendments on Meloidogyne arenaria, J.Nematol. 25,71-77.

Karmani, B. K.; Jiskani, M. M.; Khaskheli, M. I. and Wagan, K. H. (2011).Influence of organic amendments on population and reproduction of root knot nematode, Meloidogyne incognita in eggplants. Pak. J. Agri. Agril. Engg. Vet. Sci. 27 (2): 150-159.

Kaskavalvi, G. (2007). Effect of soil solarization and organic amendment treatments for controlling $M$. incognita in tomato cultivars in Western Anatolia. Turk Agri. Forum, 31: 159-167.

Kheir, A. M.; AL-Sayed, A. A. and EL-Naggar, H. I. (2000).Nematicidal potential of some ground ornamental plants against Meloidogyne incognita on sunflower. Egypt. J. Agronematol. 4(1\&2): 31-40. 
Lazarovits, G.; Tenuta, M. and Conn, K. L. (2001). Organic amendments as a disease control strategy for soil borne disease of high-value agricultural crops. Australasian Plant Pathol., 30: 111.

Maareg, M. F.; Salem, F. M. and Ebieda, A. M. (2000).Effect of certain organic and inorganic amendments on Meloidogyne javanica in sandy soil. Egypt. J. Agronematol. 4(1\&2): 83-94.

Mhinana, Z.; Mayekiso, B. and Magwa, M. L. (2010).Anatomy and morphology of Nicotiana glauca with regard to its crystals characterization. Afr. J. Plant Sci. 4:172-178.

Mian, I. H. and Rodriguez-Kabana, R. (1982). Soil amendments with oil cakes and chicken litter for control of Meloidogyne arenaria. Nematrop. 12(2), 205220.

Miano, D. W. (1999).Optmisation of carbon:nitrogen ratios in organic soil amendments for the control of root-knot nematodes (Meloidogyne spp.) in tomato. Msc. Thesis, University of Nairobi.

Mizrachi, N.; Levy, S. and Goron, Z. (2000).Fatal poisoning from Nicotiana glauca leaves: identification of Anabasine by Gas-Chromatography/mass Spectrometry. J. Forensic Sci. 45:736-741.

Moosavi, M. R. (2012).Nematicidal effect of some herbal powders and their aqueous extracts against Meloidogyne javanica. Nematrop., 42 (1): 48-56.

Muller, R. and Gooch, P. S. (1982).Organic amendments in nematode control. An examination of the literature. Nematrop. 12:319-326.

Ntalli,N.; Menkissoglu-Spiroudi, U. and Giannakou, I. (2010).Nematicidal activity of powder and extracts of Melia azedarach fruits against Meloidogyne incognita. Annals App. Biol.,156: 309-317.

Oduor-Owino, P. (1993).Effects of aldicarb, Datura stamonium, Datura metel and Tagetes minuta on the pathogenicity of root-knot nematode in Kenya. J. Crop Protec., 12(4): 315-317.

Ojo, G.T. and Umar, I. (2013).Evaluation of some botanicals on root - knot nematode (Meloidogyne javanica) in tomato (Lycopersicon esculentum, Mill) in Yola Adamawa State, Nigeria. Biologic. Forum - An International J. 5(2): 31-36(2013).

Oka, Y. (2010). Mechanism of nematode suppression by organic soil amendments. a rev. App. Soil Ecol., 44:101-115.

Oka, Y. and Pivonia, S. (2002).Use of ammonia-releasing compounds for control of the root-knot nematode. Nematol. 4: 65-71.

Onyeke, C. C. and Akueshi, C. O. (2012). Infectivity and reproduction of Meloidogyne incognita (Kofoid and White) Chitwood on African yam bean, Sphenostylis stenocarpa (Hochst Ex. A. Rich) Harms accessions as influenced by botanical soil amendments. Afri. J. Biotech., 11(67),: 1309513103Publishing House, pp: 320-322. 
Radwan, E.K.; El-Maadawy, and Abu-Elamayem, M.M. (2007).Comparison of the nematicidal potentials of dried leaves of five plant species against Meloidogyne incognita infecting tomato. Nematologia Medit., 35, 81-84.

Ramesh, P.; Panwar, N.R.; Singh, A.B. and Ramana, S. (2009).Effect of organic nutrient management practices on the production potential, nutrient uptake, soil quality, input-use efficiency and economics of mustard (Brassica juncea). Indian Agric Sci., 79:40-44.

Rao, T. V. R. and Dave, Y. S. (2001).Morpho-histogenic studies of the fruit wall of Argemone mexicana L. (Papaveraceae). Acta Botanica Hungarica, 43: 3-4, p. 391-401.

Rossner, J. and Zebitz, C. P. W. (1987). Effect of neem products on nematodes and growth of tomato (Lycopersicon esculentum). Pp. 611-621. In: Natural Plants: the Neem Tree (Azadirachta indica A. Juss.) and Other Tropical Plants (Schmutter H. and Ascher K.R.S., eds). Deutsche Ges sellschaft Fur Technische Zusammenarbes, Eschborn, Germany.

Sikora, R. A. and Fernandez, E. (2005). Nematodes parasites of vegetables, in: Plant Parasitic Nematodes in Subtropical and Tropical Agriculture, $\left(2^{\text {nd }}\right.$ edition) by Luc, M., Sikora., R. A. and Bridge, J. Chapter 7, C.A.B. International, UK, Pp.319-392.

Sukul, N. C. (1992). Plants antagonistic to plant-parasitic nematodes. Indian Review of Life Science, 12:23-52

Tsay, T.T.; Wu, T.S. and Lin, Y.Y. (2004).Evaluation of asteraceae plant for control of Meloidogyne incognita. J. Nematol., 36: 36-41.

Taylor, A. A.; Dropkin, V. H. and Martin, G. C. (1955).Perinial pattern of root-knot nematodes. Phytopathol., 45: 26 - 34.

Wani, A.H. (2006).Management of root-knot nematode, Meloidogyne incognita on okra and lentil by soil amendment with oil cakes and leaves of different plants. Nematologia Medit., 34: 83-89.

Washira, P. M.; Kimenju, J. W.; Okoth, S. A. and Miley, R. K. (2009).Stimulation of nematode destroying fungi by organic amendments applied in management of plant parasitic nematode. Asian J. Plant Sci., 3: 153-159.

Wiratno, D.; Taniwiryono, H.; Van den Berg, J. A. G.; Riksen, I. M. C. M.; Rietjens, S. R.; Djiwanti, J. E.; Kammenga and Murk, A. J. (2009).Nematicidal activity of extracts from plants was assayed against Meloidogyne incognita. The Open Natural Products J., 2: 77-85.

Youssef, M. M. A. and Lashein, A. M. S. (2013).Efficacy of different medicinal plants as green and dry leaves and extracts of leaves on root knot nematode, Meloidogyne incognita infecting eggplant. Eurasian J. Agri. and Environ. Medic. 2(1): 10-14, 2013. ISSN 1995-073X. 


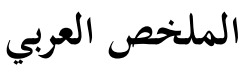

التأثير الإبادي لمطحون بعض النباتات وسبلة الدجاج ضد نيماتودا تعقد الجذور ميلويد وجين

انكوجنيتا على نباتات الطماطم

محمد راوح محمد سعيد و جمان نشأت شوكت

قسم وقاية النبات- كلية الزراعة - جامعة صنعاء

قيمت كفاءة المطحون الجاف لأوراق ؟ أنواع نباتية وسبلة الدجاج في مكافحة نيماتودا

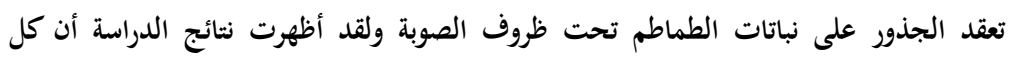

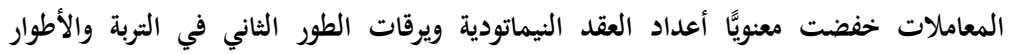

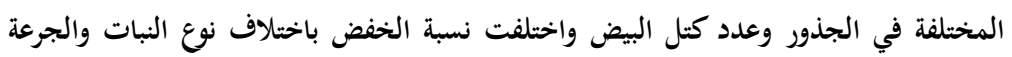

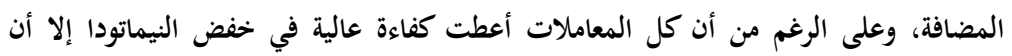

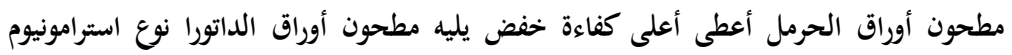
Datura stramonium

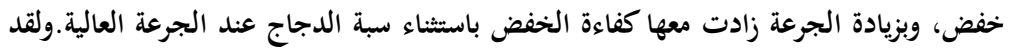

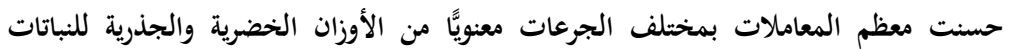

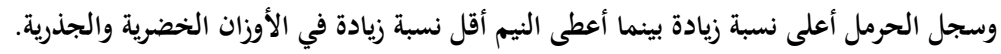

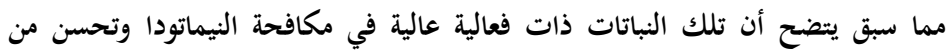
خواص التربة وكذا النمو النباتي إضافة إلى توفرها وسهولة استخدامها وعدم وجود أضرار خطيرة منها فيمكن اضافة مطحون تلك النباتات وسبلة الدجاج للتربة في برامج المكافحة المتكاملة للنيماتودا. 